\title{
A Comparative Study of Surface-Source Dispersion and Elevated-Source Dispersion
}

\author{
by \\ Shin'ichi Sakuraba, M. Moriguchi and I. Yamazi \\ Meteorological Research Institute, Tokyo \\ (Received September 30, 1969)
}

\begin{abstract}
Elevated-source dispersion is compared with simultaneous surfacesource dispersion. The analysis starts from the finding that the tracer cloud height generally varies with the downwind distance. Over a complicated terrain such as Kainan City the Pasquill stability of elevated-source dispersion is high and that of the corresponding surface-source dispersion is somewhat lower. Over a relatively flat terrain as Oita City the Pasquill stability for an elevated source is in general low or very low under weather conditions not much different from those at the Kainan City experiment. While the - Pasquill stability for a surface source is definitely higher, which is reverse to the dispersion over Kainan City.

The height of tracer cloud generally increases with the downwind distance, irrespectively of the elevated or the surface source. The rise of the tracer is more remarkable over a sloped terrain.
\end{abstract}

In the previous paper (SAKURABA, 1S69) it was shown that the tracer cloud released from an elevated source in a sea-breeze layer rises more or less with the downwind distance. The rise is larger over an urban area than over a rural area, and over a sloped terrain than over a flat terrain. In our field experiment of dispersion, the tracers were released from an elevated and a surface source simultaneously. Two kinds of FP tracer were used, one from the elevated source and the other from the surface one. It was found that the tracer cloud from the surface source also rises with the downwind distance as in the case of the elevated source. At the same time it is possible to compare the surface-source dispersion with the elevated-source one.

\section{Surface-concentration analysis when the tracer-cloud height varies with the downwind distance}

The analytical procedure for surface concentration when the tracer-cloud height varies with the downwind distance was already stated in the previous paper (SAKURABA, 1969), whose main points will be outlined in the following.

The dispersion equation is 


$$
\frac{u}{Q} C(x, y, z)=f\left[\sigma_{y}(x), \sigma_{z}(x), \bar{z}(x), y, z\right]
$$

where the relative concentration $C / Q$ is

$$
C / Q=\frac{T_{0}}{T} C(\tau) / Q
$$

$\bar{z}$ is the center-line height of tracer cloud and hereafter will be called the tracercloud height for simplicity.* $T_{0}$ is the total time required for the passage of a detached tracer plume at a point downwind under consideration and $T$ is the sampling time. $\tau$ is the release time of tracer and $C(\tau)$ is the average concentration defined by

$$
C(\tau)=\frac{1}{\tau} \int^{\tau} C^{\prime} d t
$$

$C^{\prime}$ being the instantaneous concentration.

$T_{0} / T$ is in most cases unity. The other notations are customary ones. In our experiment $\tau$ is usually $30 \mathrm{~min}$., while $T_{0}$ or $T$ is not always equal to $\tau$, as pointed out from the data of time-sequential sampler (SAKURABA, 1969).

The equation of surface concentration is

$$
u C_{a} / Q=f\left[\sigma_{y}(x), \sigma_{z}(x), \bar{z}(x), 0,0\right]
$$

where $C_{a} \equiv C(x, o, 0)$ is the axial concentration at the surface. Here $\sigma_{y}(x)$ and $C_{a}$ are readily derivable from the surface concentration pattern. The transport speed $u$ may be decided from the arrival time of the tracer in the light of time-sequential sampler record. At one point or two downwind we have the vertical concentrationprofile data, from which the tracer-cloud height $\bar{z}$ and the vertical dispersion parameter $\sigma_{z}$ are determined.** Then the source intensity $Q$ may be decided. The constancy of $Q$ may be checked if the concentration profile data are available at two points downwind. In the case of an elevated source such check was possible and it was found that $Q$ is fairly constant down to at least $5 \mathrm{~km}$ distance. In the case of a surface source the concentration-profile data are usually available at only one point downwind. However it does not seem that the transit loss of FP tracer is so large as to affect seriously the estimation of $\bar{z}$ in the range of $5 \mathrm{~km}$ downwind, since the analyzed $\bar{z}$ varies rather reasonably with the downwind distance as will be shown later. The recent study (VAUGHAN and MCMULLEN, 1968) shows that the transit loss of FP tracer disseminated from near the ground is negligibly small for travel distances ranging from 4 to $29 \mathrm{~km}$ over urban areas.

Qualitatively speaking, with $Q$ decided from the concentration profile sounding at one point between the source site and the outermost are of network, $\bar{z}$ tends to

\footnotetext{
* Hitherto $\bar{z}$ was taken as the Iracer-release height or the source height.

* The Gaussian distribution of concentration is assumed along the vertical.
} 
be underestimated near the source and over-estimated downwind of the sounding site, assuming that $Q$ decreases uniformly with the downwind distance and that the other conditions are the same.

Now we got $\vec{z}$ and $\sigma_{z}$ at one point or two downwind. From $\sigma_{z}$ the corresponding Pasquill stability may be determined (TURNER, 1967). In the case of an elevated source the Pasquill stability thus decided is approximately constant down to $5 \mathrm{~km}$ distance. This is applicable to the surface-source dispersion, since the tracer cloud rises in most cases remarkably with the downwind distance.

Thus, there now remains only one unknown, $\bar{z}(x)$, in the dispersion equation (4) and the tracer-cloud height may be estimated therefrom.

\section{Kainan City experiment}

Kainan, lying to south of Wakayama City, is a city situated in a narrow valley surrounded north and south by mountains about 150 to $400 \mathrm{~m}$ high and extends eastwestwards. The west end of the city is open to the sea. The tracers were released simultaneously from $200 \mathrm{~m}$ source and the surface source placed near the coast. The tracers flowed in over Kainan City with the west wind.

\subsection{2:00 7th August 1968}

The vertical distributions of wind direction, wind speed and temperature near the source are shown in Figs. 1, 2 and 3 respectively. A large shear of wind direction occurs at $12: 30$ and the wind speed decreases with height up to 300 or 400 $\mathrm{m}$ level. The lapse rate of temperature is about $0.5^{\circ}$ to $0.6^{\circ} \mathrm{C} / 100 \mathrm{~m}$ except in the shallow layer adjacent to the ground. The depth of this shallow and unstable layer is perhaps smaller than that depicted in the figure. In Fig. 4, $\mathrm{H}_{2}$ shows the temperature profile near the source or the coast and $\mathrm{H}_{1}$ that at $3.8 \mathrm{~km}$ downwind of $\mathrm{H}_{2}$. It is seen that the modification of sea breeze extends up to $400 \mathrm{~m}$ level.

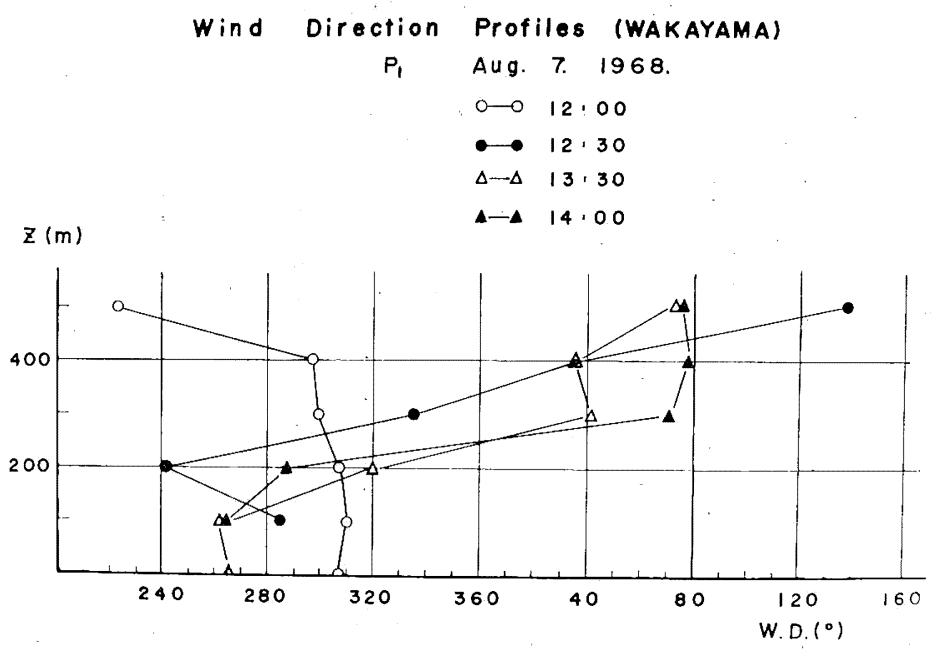

Fig. 1. Wind direction profiles (12:00-14:00 7th Aug., Kainan City). 

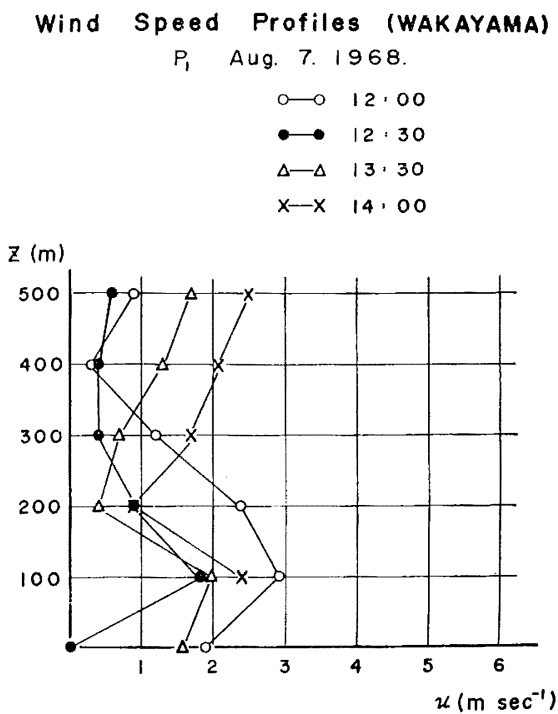

Fig. 2. Wind speed profiles (12:00-14:00 7th Aug., Kainan City).

Temperature Profiles (Wakayama)

Aug. 7. 1968.

$K \quad 0 \quad 12,24$

$z(m)$

$H \leftrightarrow|2,3|$

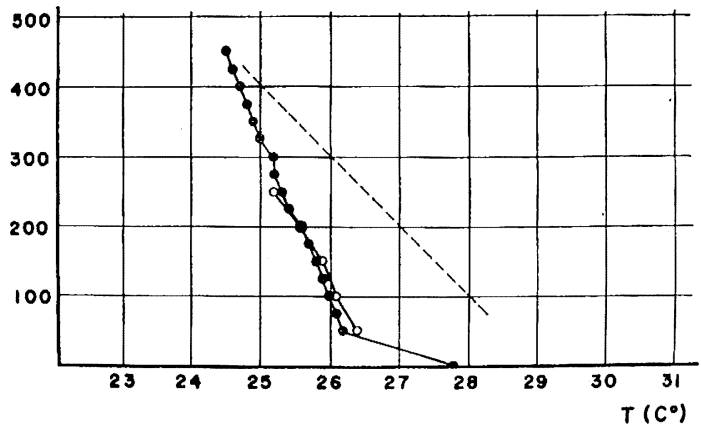

Fig. 3. Temperature profiles (12:30 7th Aug., Kainan City). $\mathrm{K}$ : sounding by kytoon $\mathrm{H}$ : sounding by helicopter dotted line: dry adiabat. 
Temperature Profiles (WAKAYAMA)

Aug. 7. 1968.

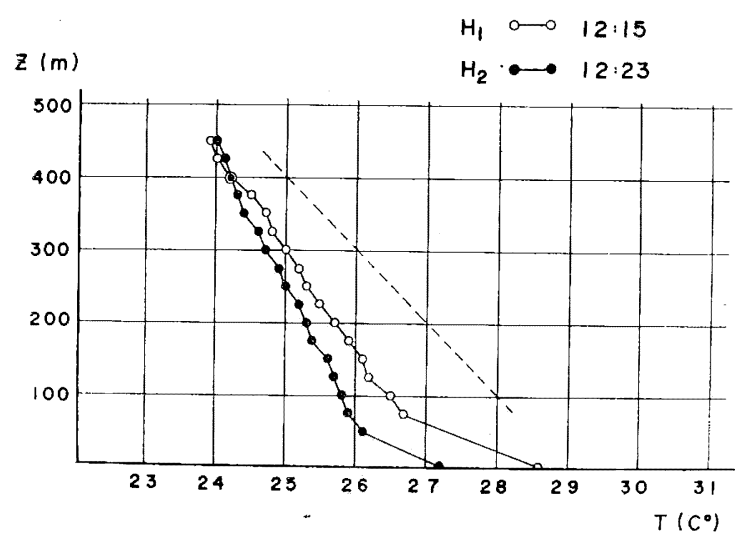

Fig. 4. Temperature profiles near the coast and inland (Kainan City). $\mathrm{H}_{2}$ : near the coast $\mathrm{H}_{1}$ : at $3.8 \mathrm{~km}$ inland.

(a) $200 \mathrm{~m}$-source dispersion Fig. 5 shows the concentration profile at $x=550 \mathrm{~m}$, $x$ being the downwind distance. $\bar{z}$ is $154 \mathrm{~m}$ and $\sigma_{z}$ is $33 \mathrm{~m}$, thus the Pasquill stability is C. Fig. 6 is the same, but for $x=1.5 \mathrm{~km}$. Here the ordinate is the ratio to the surface concentration and the abscissa is $z / \bar{z}$, parameter $\xi$ being $\sigma_{z} / \bar{z}$. Fig. 6 shows that $\bar{z}$ is $200 \mathrm{~m}$ and $\sigma_{z}$ is $126 \mathrm{~m}$, then the Pasquill stability is B-C. Namely, two kinds of Pasquill stability were got, B-C and $\mathrm{C}$. One seemingly reasonable explanation is that the Pasquill stability changed from $\mathrm{C}$ at $x=550 \mathrm{~m}$ to $\mathrm{B}-\mathrm{C}$ at $x=1.5 \mathrm{~km}$, accompanying the modification of sea breeze and/or the increase of roughness inland. This

Aug 7. 1968 (WAKAYAMA)

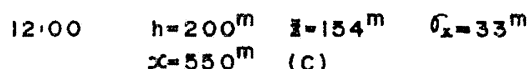

$x=550^{m} \quad$ (c)

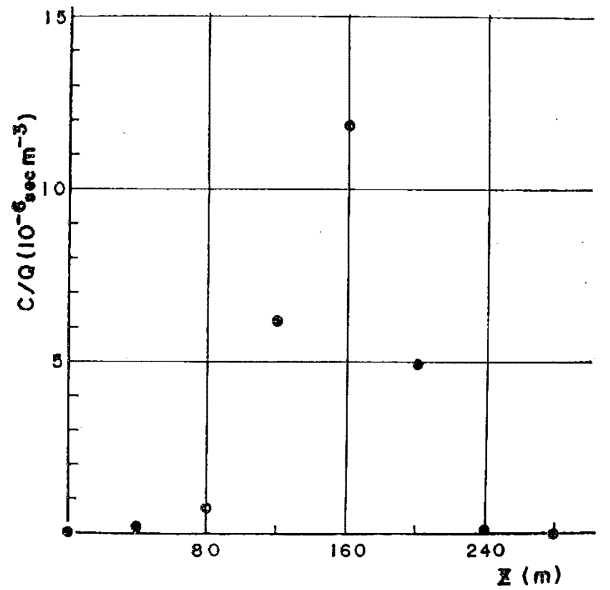

Fig. 5. Concentration profile at $550 \mathrm{~m}$ downwind of $200 \mathrm{~m}$-source (12:00 7th Aug., Kainan City). 


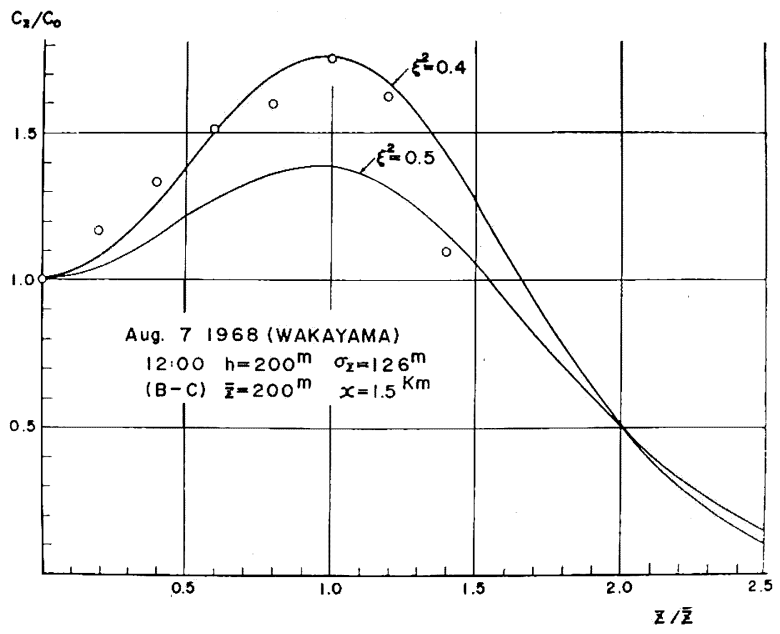

Fig. 6. Same as Fig. 5 but for $1.5 \mathrm{~km}$ downwind.

$C(x, y, z) / C(x, y, 0)=\left[\exp \left\{-(\eta-1)^{2} / 2 \xi^{2}\right\}+\exp \left\{-(\eta+1)^{2} / 2 \xi^{2}\right\}\right] / 2 \exp \left(-1 / 2 \xi^{2}\right)$, $\xi=\sigma_{z} / \bar{z}, \quad \eta=z / \bar{z}$.

is not, however, acceptable, since there occur some instances of the Pasquill stability becoming lower with the downwind distance under the similar circumstance to this case. The other possibility is that this is beyond the accuracy of analysis so far as the small difference of Pasquill stability between $\mathrm{B}-\mathrm{C}$ and $\mathrm{C}$ is concerned. In the other runs of Kainan City experiment the Pasquill stability is B or B-C for $200 \mathrm{~m}$ source, so in this case also the Pasquill stability B-C will be adopted.

Fig. 7 shows the sampling network of the Kainan City experiment. Fig. 8 is the result of surface concentration analysis made by the procedure stated in the previous section. Here the ordinate is the normalized axial concentration at the surface in $\mathrm{m}^{-2}$ and the abscissa is the downwind distance in $\mathrm{km}$. The curve is the isoline of $\bar{z}$ in meters when the Pasquill stability is B-C. The white circle shows only how the surface axial concentration normalized varies with the downwind disstance and has no connection with $\bar{z}$, while the black circle shows the surface concentration modified so that $\sigma_{y}$ conforms to that in Pasquill stability B-C. This is because $\sigma_{y}$ and $\sigma_{z}$ are usually different in Pasquill stability. As seen from Fig. 8, at $550 \mathrm{~m}$-arc and $1.5 \mathrm{~km}$-arc, $\sigma_{y}$ is almost the same as that of stability B-C in the Pasquill chart, so the two circles coincide in location. At $3.0 \mathrm{~km}$-arc, on the other hand, the analyzed $\sigma_{y}$ is larger than that of B-C in the Pasquill chart, so the actual $\sigma_{y}$ is replaced by that in the Pasquill chart. Thus the axial concentration increases by that amount. $\bar{z}$ can be read from the location of the black circle in Fig. 8.

The result is summarized as follows.

\begin{tabular}{c|ccccc}
\hline \hline$x$ & $(0)$ & $(0.55)$ & $(1.5)$ & 3.0 & $5.0 \mathrm{~km}$ \\
\hline $\bar{z}$ & $(200)$ & $(154)$ & $(200)$ & 250 & $450 \mathrm{~m}$ \\
\hline
\end{tabular}

Here $\bar{z}$ shows values estimated from the surface concentration except those in brackets which include the direct analysis of the concentration profile or are the 


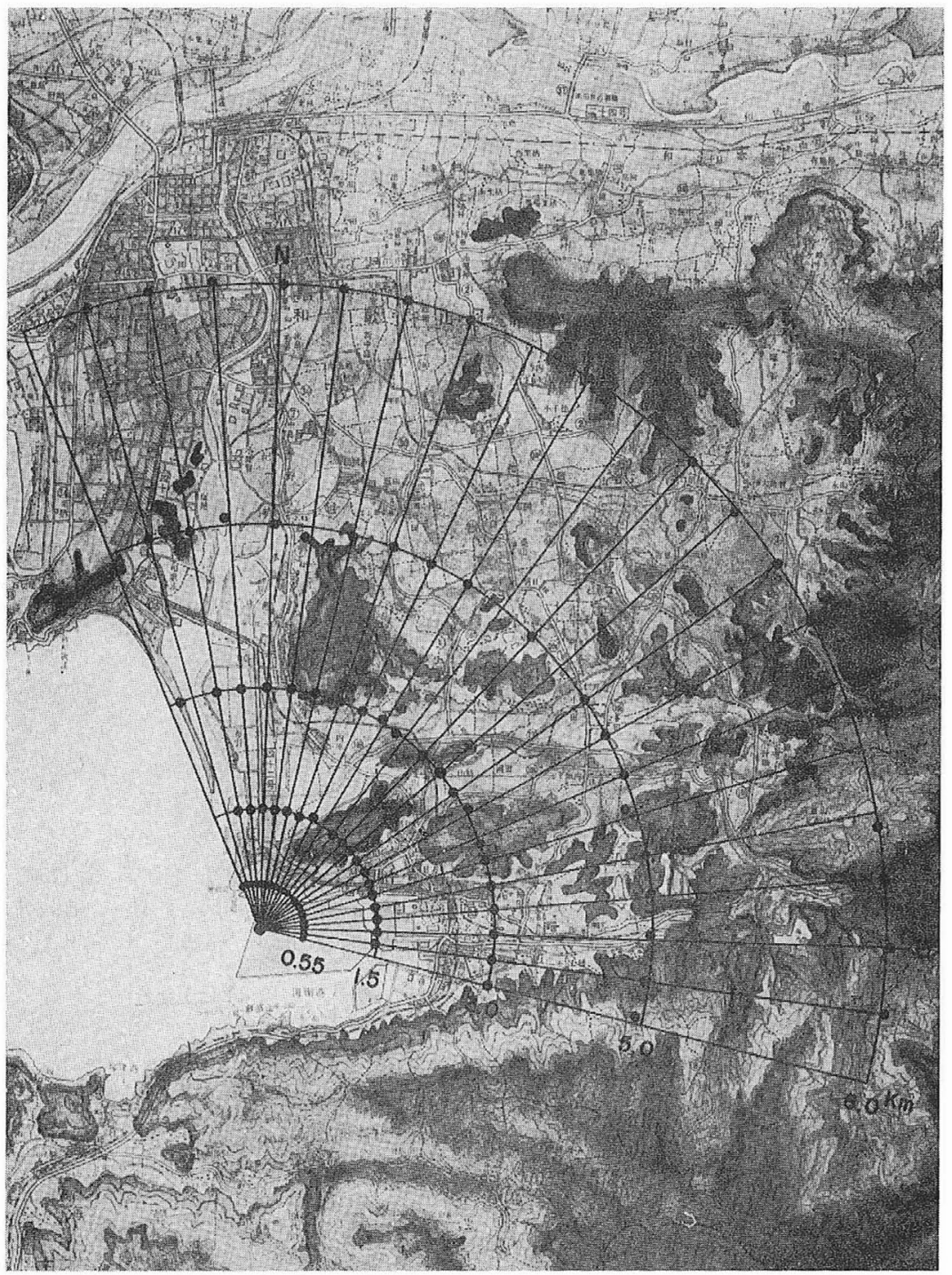

Fig. 7. Sampling network of Kainan City experiment.

source heights.

The tracer descends about $50 \mathrm{~m}$ at $550 \mathrm{~m}$-arc, resumes its initial height at 1.5 $\mathrm{km}$-arc and then begins to rise remarkably. At about $150 \mathrm{~m}$ east of the source there is a building $50 \mathrm{~m}$ or so high, which seems to have affected the descent of the tracer at $550 \mathrm{~m}$-arc. This is also reflected in the concentration profile from the surface source, as will be shown next.

(b) Surface-source dispersion The vertical concentration profile corresponding to the surface source was obtained at $x=1.5 \mathrm{~km}$ (Fig. 9). $\bar{z}$ is $130 \mathrm{~m}$ and $\sigma_{z}$ is $82 \mathrm{~m}$, the Pasquill stability being C. Fig. 10 is one corresponding to Fig. 8. The tracer- 


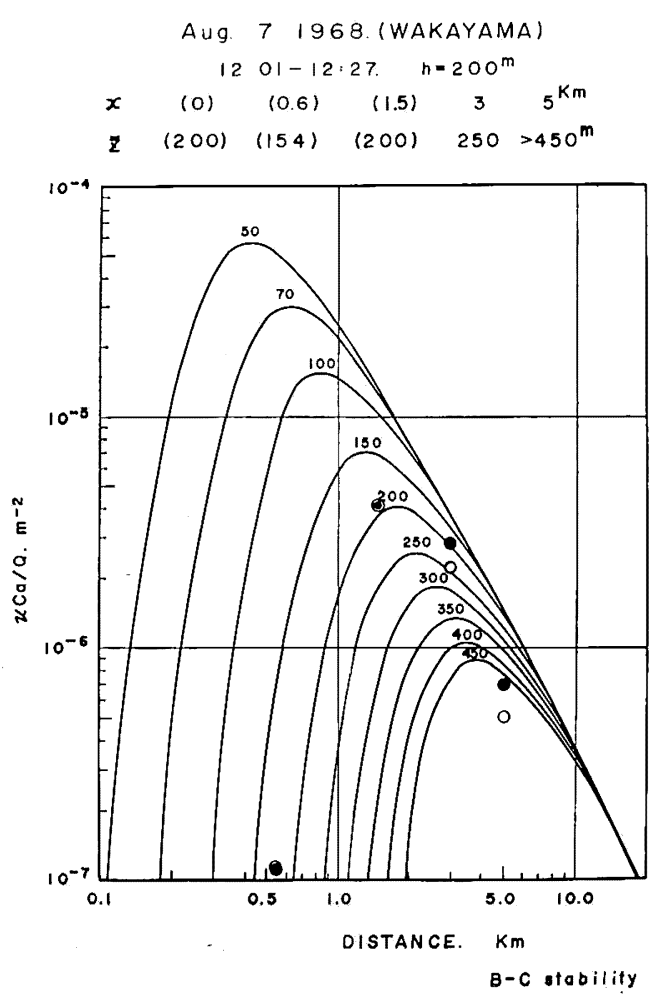

Fig. 8. Surface axial concentration vs. downwind distance curve in case of Pasquill stability B-C. Numeral labelled shows the tracer cloud height in meter (12:00 7th Aug., Kainan City).

cloud height varies as follows.

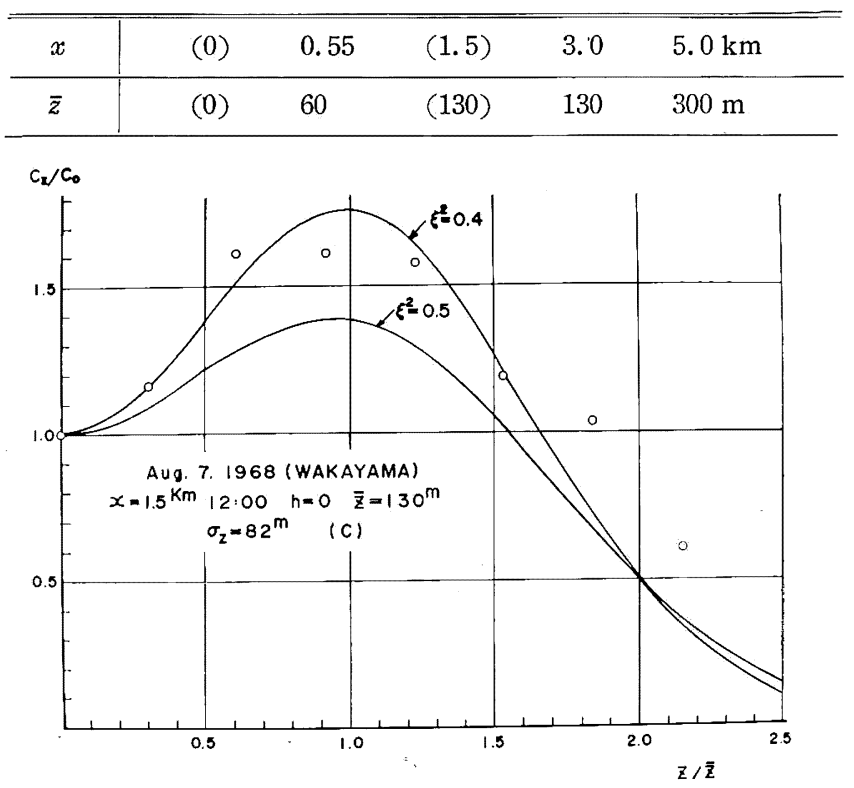

Fig. 9. Same as Fig. 6 but for the surface source. 


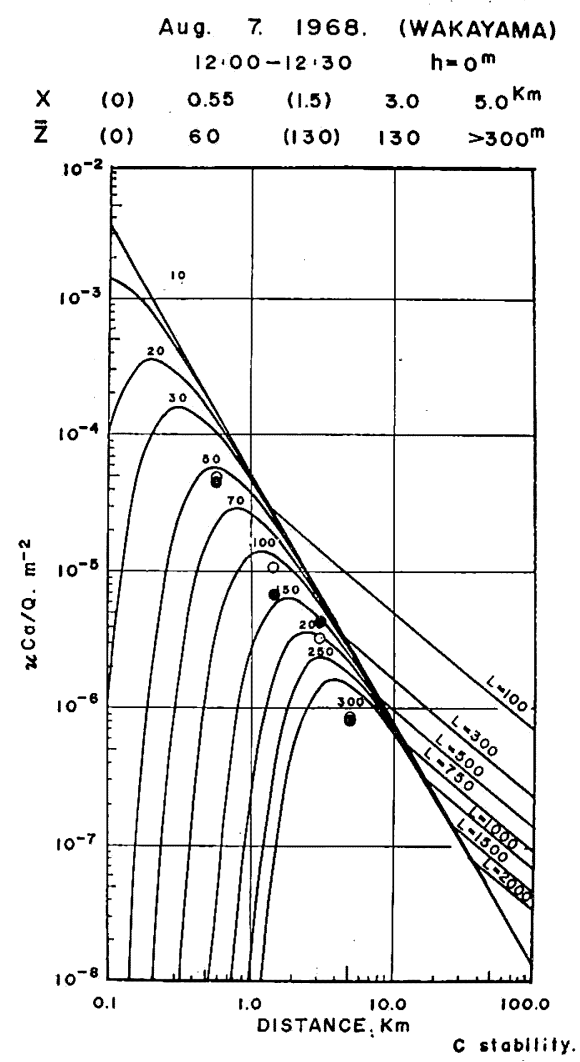

Fig. 10. Same as Fig. 8 but for Pasquill stability $\mathrm{C}$ and surface source.

The rise of the tracer cloud with the downwind distance is remarkable. It is evident that the analysis hitherto made assuming no rise of the tracer cloud will overstimate $\sigma_{z}$ seriously under this circumstance.

\subsection{0:30 8th August 1968}

The wind and the temperature profiles are shown in Figs. 11 to 13. There is no
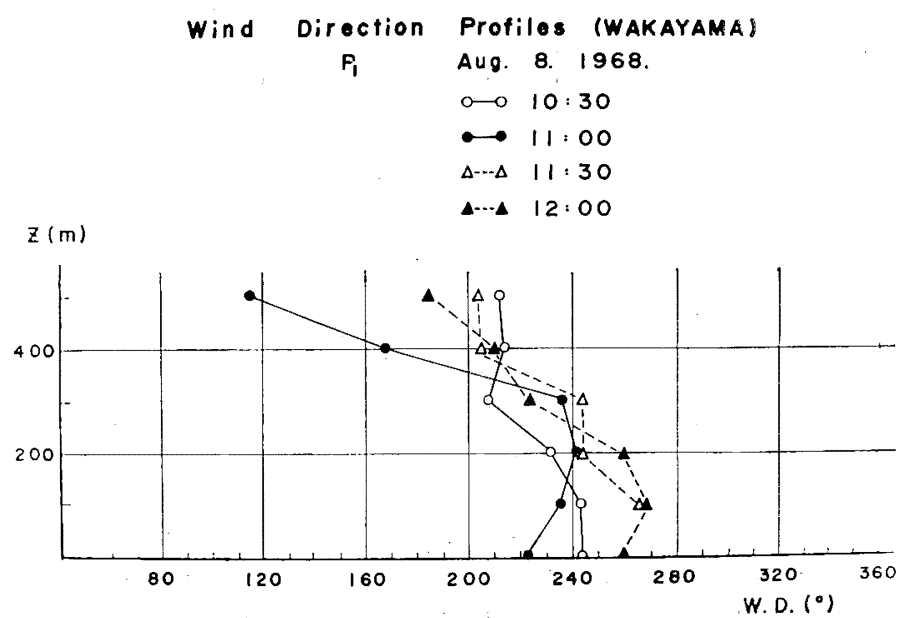

Fig. 11. Same as Fig. 1 but for 10:30-12:00 8th. 


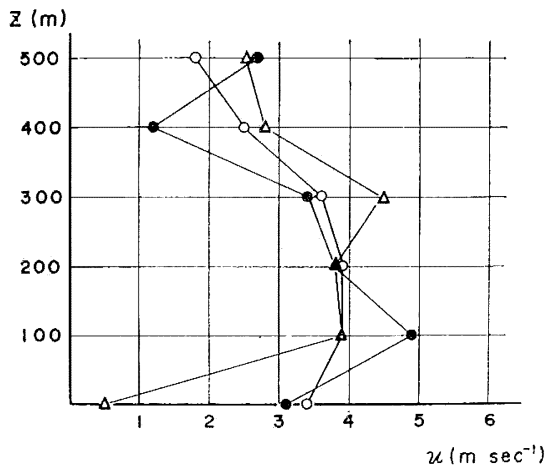

Fig. 12. Same as Fig. 2 but for $10: 30-12: 008$ th.

large shear of wind direction up to the $300 \mathrm{~m}$ level, in contrast to 12:00 7th. The wind speed decreases from the $300 \mathrm{~m}$ level upwards. According to the time-sequential sampler at $x=5.0 \mathrm{~km}$, the transport speed of the tracer for the $200 \mathrm{~m}$ source is $1.8 \mathrm{~m}$ $\sec ^{-1}$, which, in the light of Fig. 12, suggests the rise of the tracer cloud. The stratification is unstable compared with the previous day and near neutral between $200 \mathrm{~m}$ and $300 \mathrm{~m}$ level.

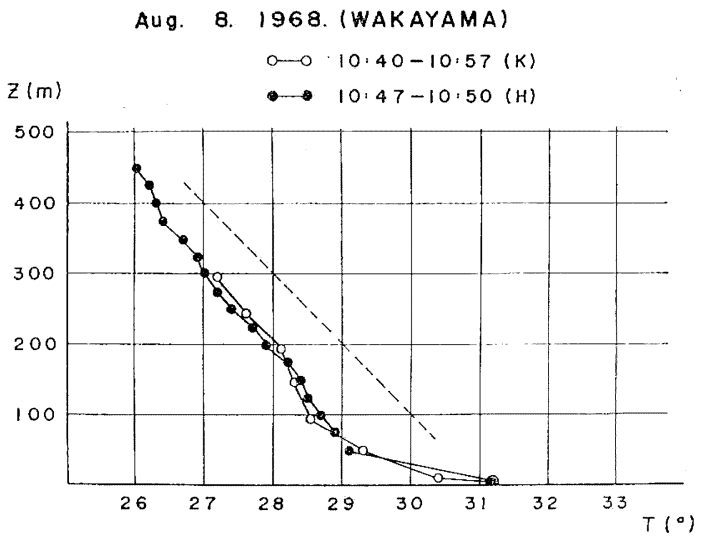

Fig. 13. Same as Fig. 3 for 10:50 8th.

(a) $200 \mathrm{~m}$-source dispersion Fig. 14 shows the concentration profile at $x=550 \mathrm{~m}$. $\bar{z}$ is $194 \mathrm{~m}$ and $\sigma_{z}=53 \mathrm{~m}$, the Pasquill stability being B. Fig. 15 shows the result of analysis. $\bar{z}$ varies with the downwind distance as follows. 
Aug. 8. 1968 (WAKAYAMA)

O $10: 30 \quad h=200^{m} \quad X=550^{m} \quad \sigma_{z=53^{m}}^{m} \quad \bar{z}=194^{m} \quad(B)$

- 12:30 $\quad h=200^{m} \quad X=550^{m} \quad \sigma_{z=43^{m}} \quad z=196^{m} \quad(B-C)$

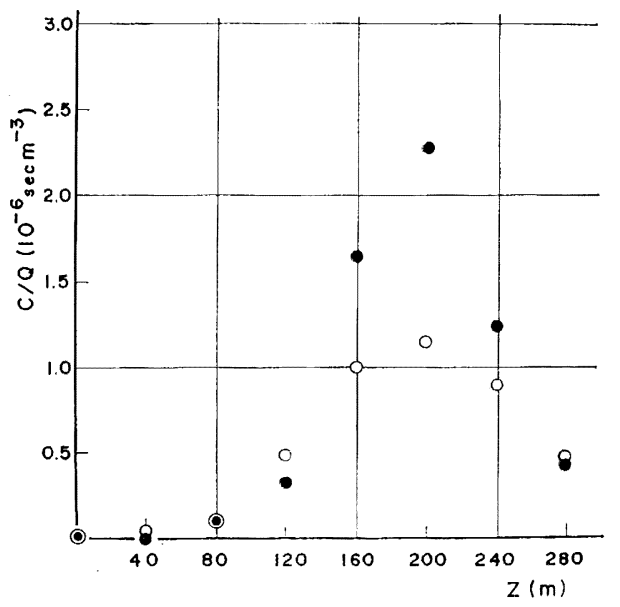

Fig. 14. Same as Fig. 5 but for 10:30 8th.

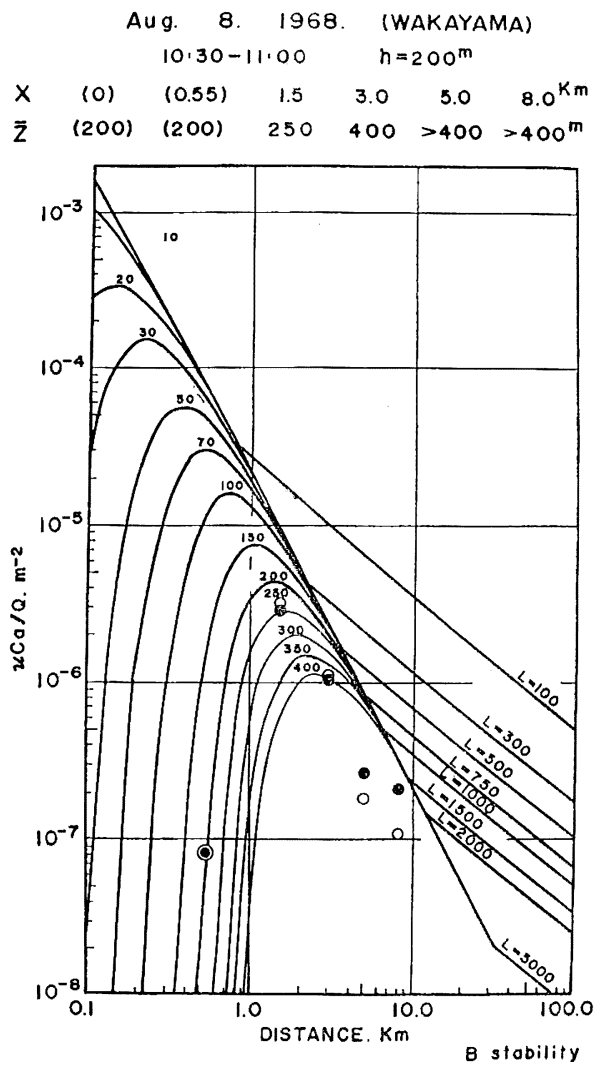

Fig. 15. Same as Fig. 8 but for Pasquill stability B and 10:30 8th. 


\begin{tabular}{c|cccccc}
\hline \hline$x$ & $(0)$ & $(0.55)$ & 1.5 & 3.0 & 5.0 & $8.0 \mathrm{~km}$ \\
\hline $\bar{z}$ & $(200)$ & $(200)$ & 250 & 400 & $>400$ & $>400 \mathrm{~m}$ \\
\hline
\end{tabular}

The rise of the tracer cloud is more remarkable than on the previous day. The wind direction at this time was WSW, so the effect of the building due east of the source is not seen. At $1.5 \mathrm{~km}$ arc a part of the tracer cloud hit the hills to the north of Kainan City. The large rise of the tracer cloud is perhaps due to this circumstance.

(b) Surface-source dispersion Fig. 16 shows the concentration profile at $x=$

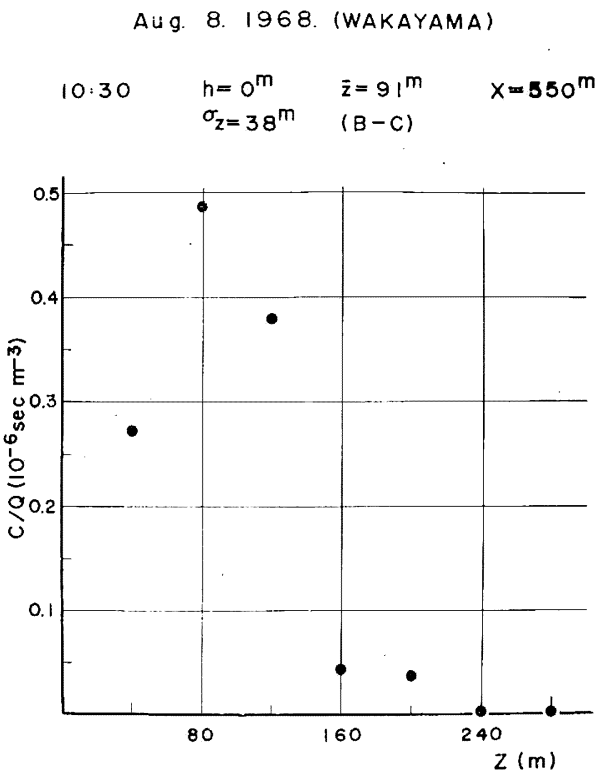

Fig. 16. Same as Fig. 5 but for surface source and 10:30 8th.

$550 \mathrm{~m} . \bar{z}$ is $90 \mathrm{~m}$ and $\sigma_{z}$ is $38 \mathrm{~m}$, the Pasquill stability being B-C. Fig. 17 is the result of analysis and $\bar{z}$ varies as follows.

\begin{tabular}{l|lll}
\hline$x$ & $(0)$ & $(0.55)$ & $1.5 \mathrm{~km}$ \\
\hline $\bar{z}$ & $(0)$ & $(100)$ & $290 \mathrm{~m}$ \\
\hline
\end{tabular}

The rise of the tracer cloud is larger than the corresponding one of the previous day.

\subsection{Characteristics of dispersion over Kainan City}

Taking into account the other runs of the experiment not cited here, the characteristics of dispersion at the Kainan area are as follows. The Pasquill stability is high, being $\mathrm{B}$ or $\mathrm{B}-\mathrm{C}$ for $200 \mathrm{~m}$-source. The topographic conditions seem to have 


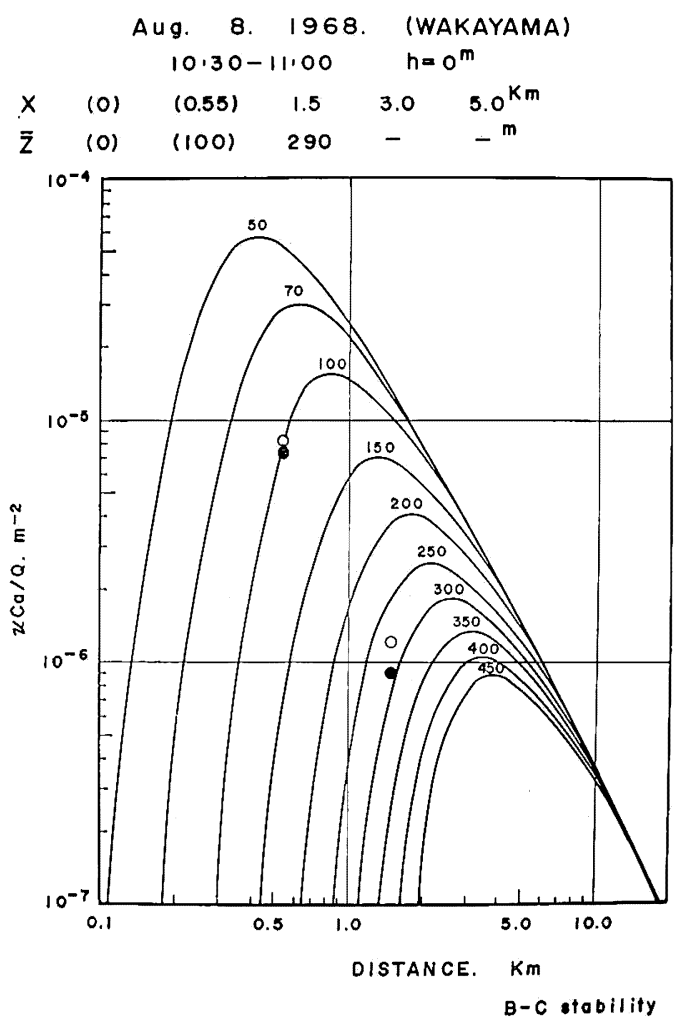

Fig. 17. Same as Fig. 8 but for surface source and 10:30 8th.

much to do with this situation. In rather flat areas, under almost the same meteorological conditions, such high stability is notface source is somewhat lower than that of very low. The Pasquill stability of the sur observed, except when the wind speed is the $200 \mathrm{~m}$ source, which is reverse to the dispersion in a flat area, as will be seen in the following section.

\section{Oita experiment}

Fig. 18 shows the sampling network of the Oita experiment. Two sources, the $150 \mathrm{~m}$ and the surface source, were sited near the coast. Generally speaking, the ground is flat down to $3.0 \mathrm{~km}$ arc, beyond which there are table lands 40 or $50 \mathrm{~m}$ high. In the western part of the network, however, the terrain is flat down to 7.0 $\mathrm{km}$ arc, the outermost arc, which comprises the congested area of Oita City.

\subsection{4:00 25th August 1968}

Figs. 19 and 20 show the wind profiles near the source. The wind veers upwards from the $200 \mathrm{~m}$ or $300 \mathrm{~m}$ level. The wind speed decreases with height. The transport speed of the tracer determined from the record of time-sequential sampler is, between the source and $2.6 \mathrm{~km}$ downwind, $4.3 \mathrm{~m} \mathrm{sec}^{-1}$ for both the $150 \mathrm{~m}$ source and the surface source, while, between $2.6 \mathrm{~km}$ and $4.7 \mathrm{~km}$, the transport speed is 


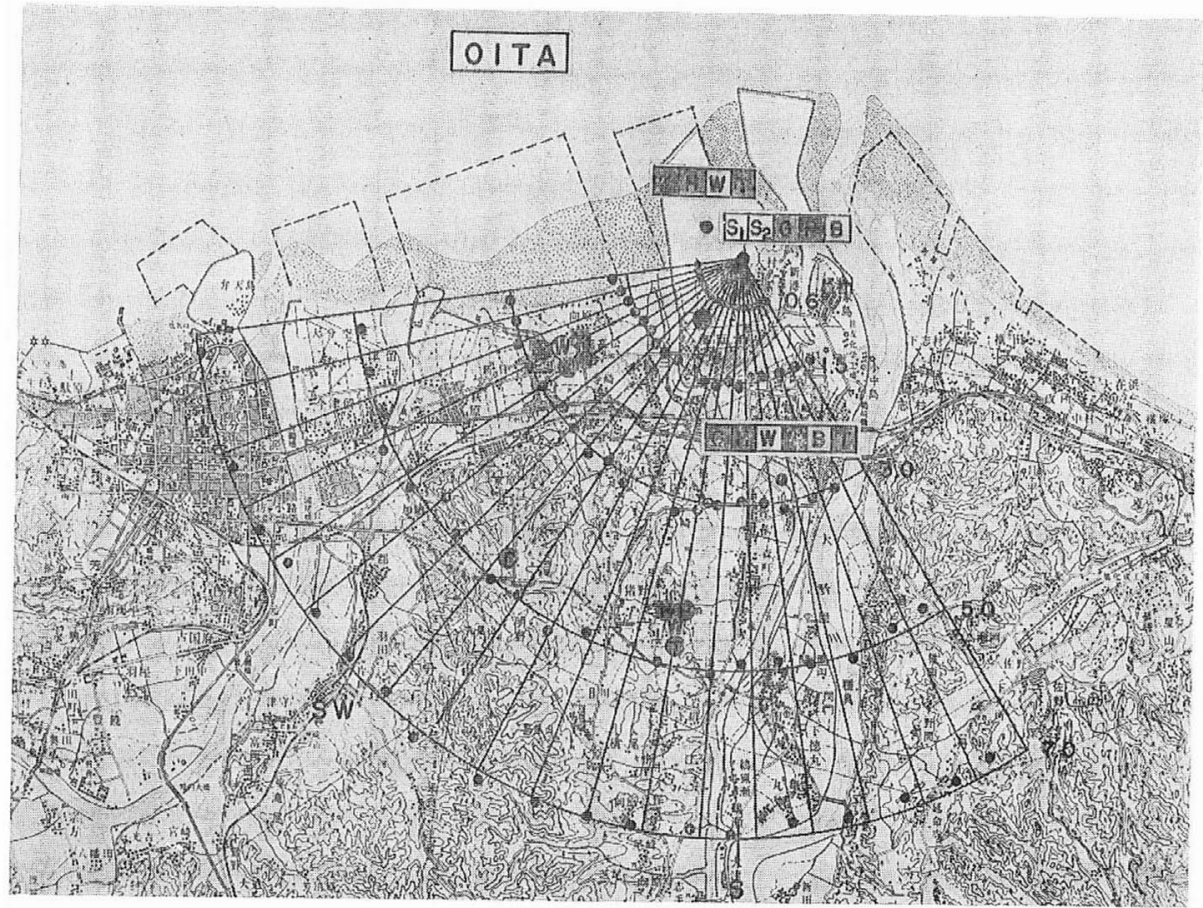

Fig. 18. Sampling network of Oita experiment.

$0.7 \mathrm{~m} \mathrm{sec}^{-1}$ for the $150 \mathrm{~m}$ source and $1.1 \mathrm{~m} \mathrm{sec}^{-1}$ for the surface source. This, compared with the wind speed profile in Fig. 20, suggests the rise of the tracer with the downwind distance.

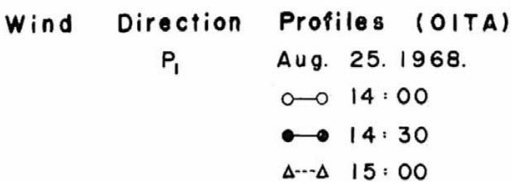

$z(m)$

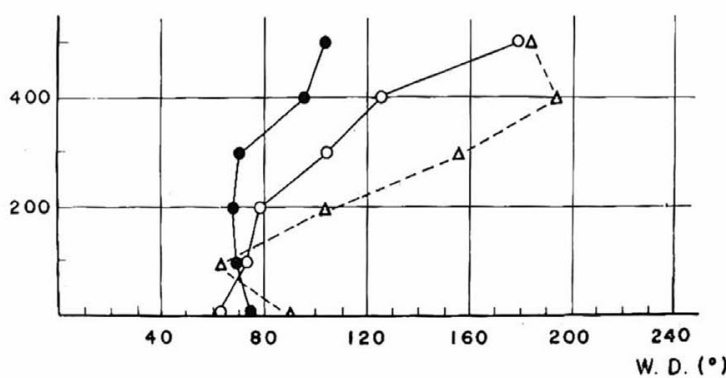

Fig. 19. Wind direction profiles (14:00-15:00 25th Aug., Oita City).

The temperature profile near the source is shown in Fig. 21. Except for the shallow unstable layer close to the ground, the stratification is stable. Below the $150 \mathrm{~m}$ level there is seen a near-isothermal layer. Fig. 22 shows the modification of sea 
Wind Speed Profiles (OITA)

$P_{1}$ Aug. 25. 1968 .

$014: 00$

$\longrightarrow 14: 30$

$\Delta \cdots \Delta 15: 00$

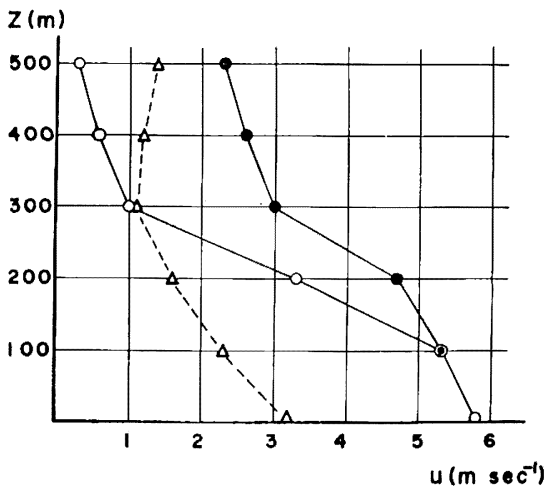

Fig. 20. Wind speed profiles (14:00-15:00 25th Aug., Oita City).

breeze inland. Here $\mathrm{H}_{2}$ is near the source and $\mathrm{H}_{1}$ is at $2.6 \mathrm{~km}$ downwind. The modification extends up to the $100 \mathrm{~m}$ level at $2.6 \mathrm{~km}$ downwind, the lower isothermal layer disappearing.

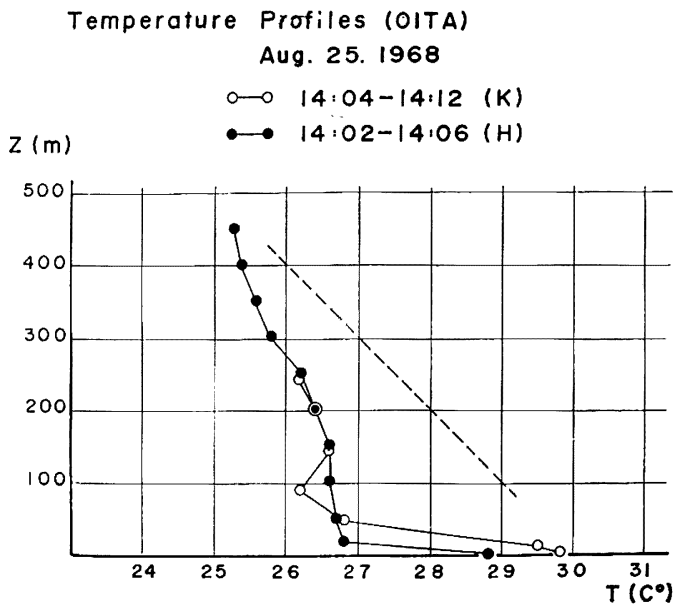

Fig. 21. Temperature profiles (14:00 25th Aug., Oita City).

(a) 150 m-source dispersion Fig. 23 shows the concentration profile at $x=2.6$ $\mathrm{km} . \bar{z}$ is $137 \mathrm{~m}$ and $\sigma_{z}$ is $48 \mathrm{~m}$, the Pasquill stability being D-E. The result of analysis is shown by Fig. 24, with the same representation as in Fig. 8. It is seen that $\bar{z}$ varies with the downwind distance as follows.

\begin{tabular}{l|llllll}
\hline$x$ & $(0)$ & 1.5 & $(2.6)$ & 3.0 & 5.0 & $7.0 \mathrm{~km}$ \\
\hline $\bar{z}$ & 150 & 125 & $(137)$ & 140 & 210 & $250 \mathrm{~m}$ \\
\hline
\end{tabular}




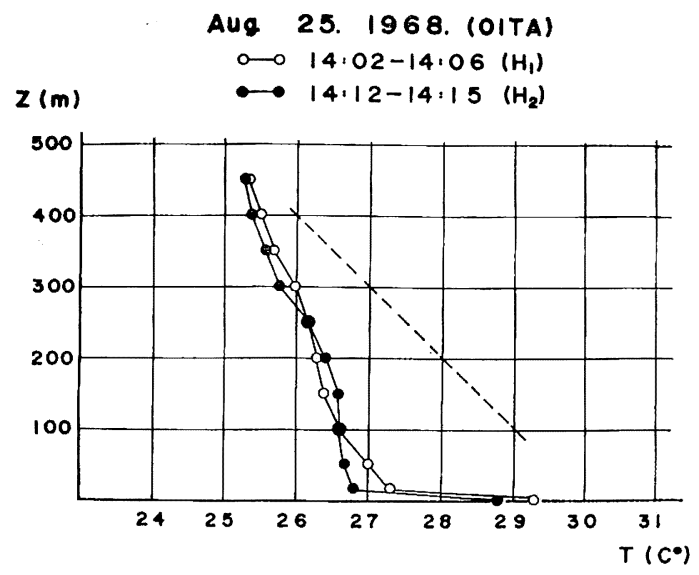

Fig. 22. Temperature profiles near the coast and inland.

$\mathrm{H}_{2}$ : near the coast $\mathrm{H}_{1}$ : at $2.6 \mathrm{~km}$ inland.

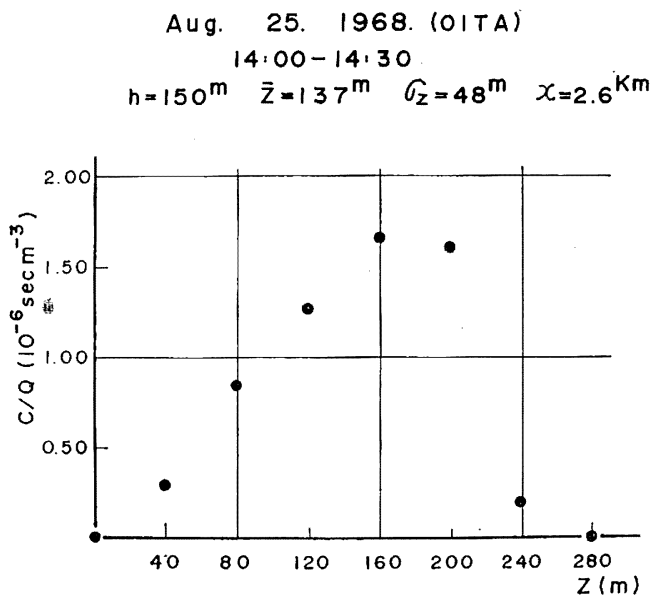

Fig. 23. Concentration profile at $2.6 \mathrm{~km}$ downwind of $150 \mathrm{~m}$-source (14:00 25th Aug., Oita City).

In this case the tracer first flowed towards WSW and at $5.0 \mathrm{~km}$ downwind turned to the south, round the periphery of the table land area. This means that the tracer flowed over a flat area all the way down to $7.0 \mathrm{~km}$-arc. The tracer cloud somewhat descended near the source, from some unknown cause. Then it rose steadily with the downwind distance.

(b) Surface-source dispersion The concentration profile at $x=2.6 \mathrm{~km}$ is shown in Fig. 25. There $\bar{z}$ is $60 \mathrm{~m}$ and $\sigma_{z}$ is $60 \mathrm{~m}$, the Pasquill stability being $\mathrm{D}, \bar{z}$ varies as follows (Fig. 26).

\begin{tabular}{c|cccccc}
\hline \hline$x$ & $(0)$ & 0.6 & 1.5 & $(2.6)$ & 3.0 & $5.0 \mathrm{~km}$ \\
\hline $\bar{z}$ & $(0)$ & 0 & 30 & $(60)$ & 60 & $90 \mathrm{~m}$ \\
\hline
\end{tabular}




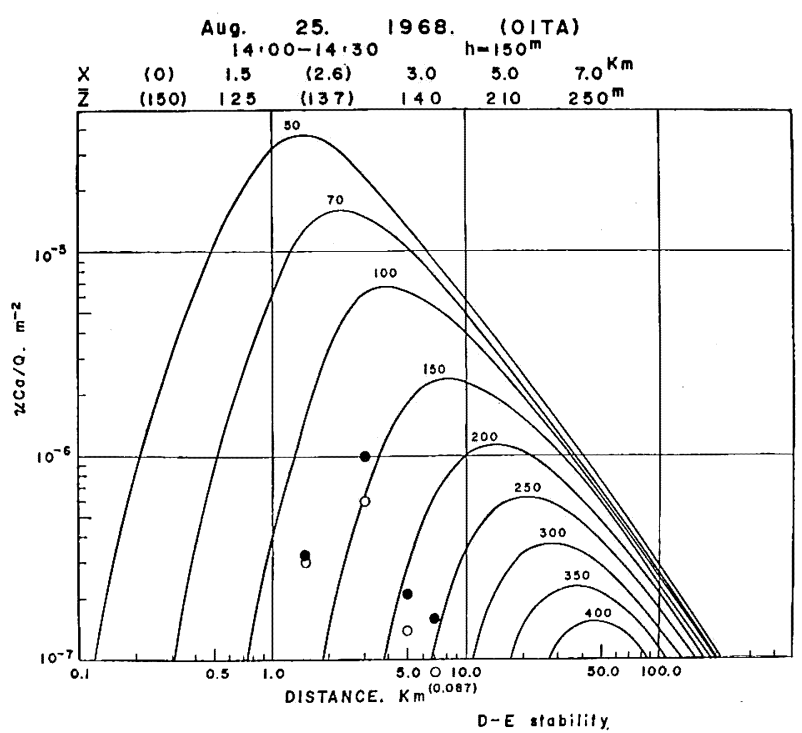

Fig. 24. Surface axial concentration vs. downwind distance curve in case of Pasquill stability D-E (14:00 25th Aug., Oita City).

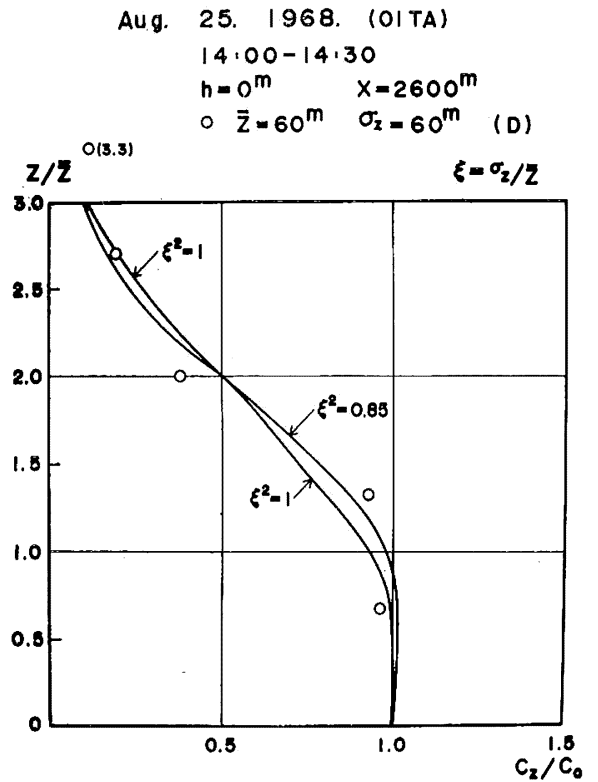

Fig. 25. Same as Fig. 23 but for surface source.

It must be noticed here that the central part of the tracer cloud climbed over the table land at $5.0 \mathrm{~km}$-arc. Many examples show that the rise of the tracer cloud is especially remarkable over an elevated terrain. The Pasquill stability of surfacesource dispersion is somewhat higher than than that of $150 \mathrm{~m}$-source dispersion simultaneously released. 


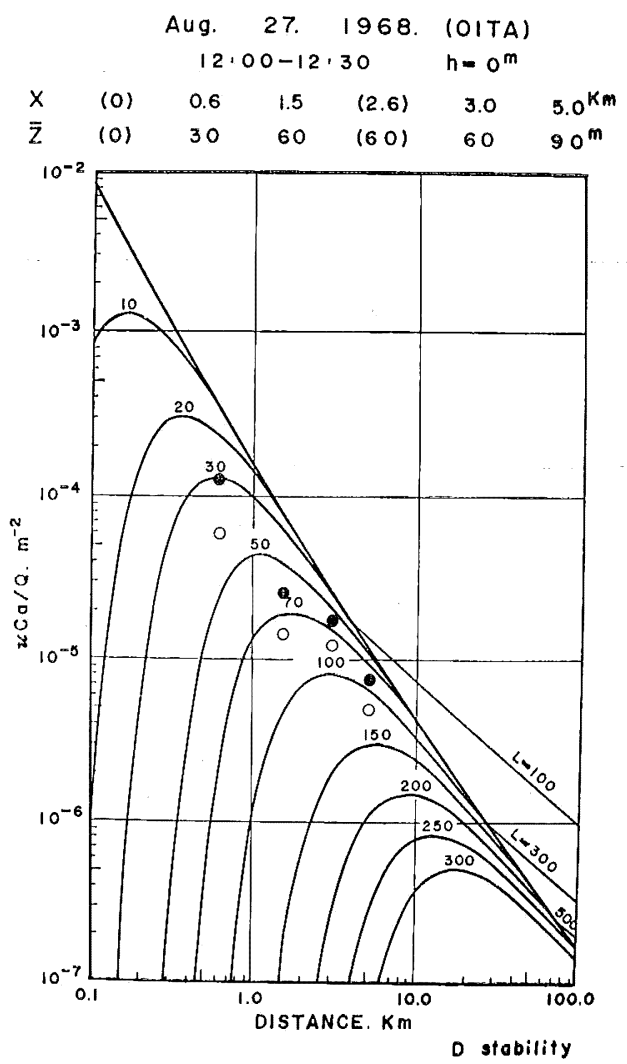

Fig. 26. Same as Fig. 24 but for Pasquill stability D and surface source.

\subsection{0:00 27th August 1968}

Figs. 27 and 28 show the wind profiles near the source, while Fig. 29 shows the temperature profiles both at the source and inland. It is to be noticed that the modification inland does not affect the stability.

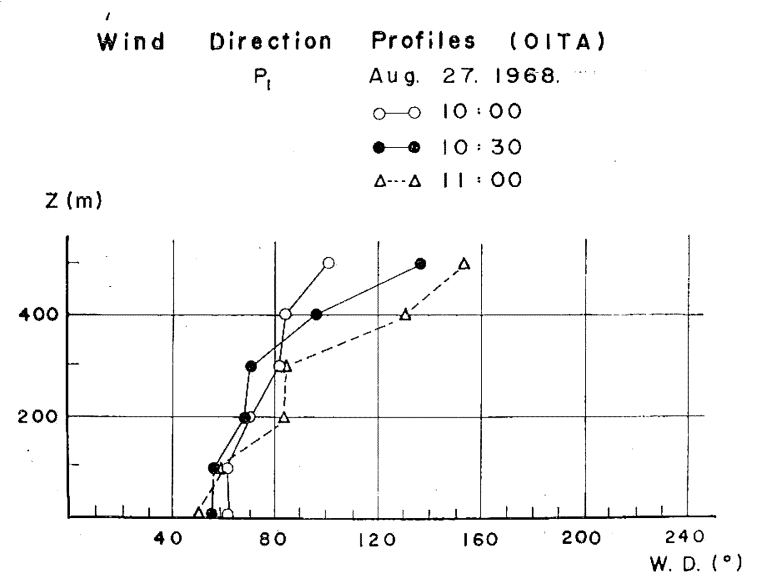

Fig. 27. Same as Fig. 19 but for 10:00-11:00 27th. 

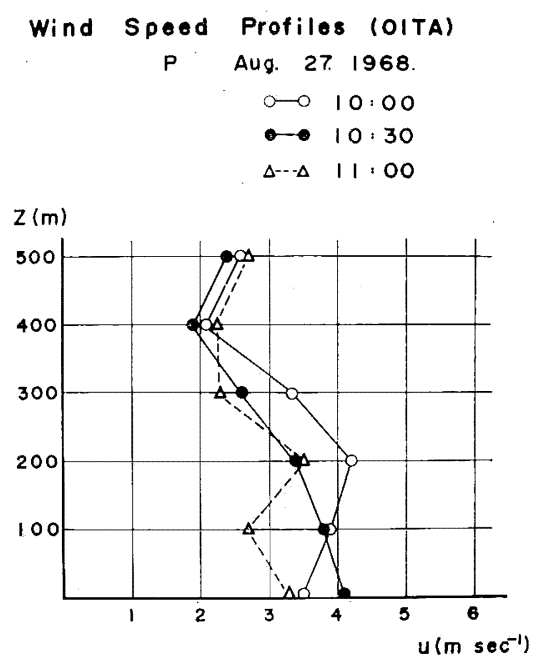

Fig. 28. Same as Fig. 20 but for 10:00-11:00 27th.

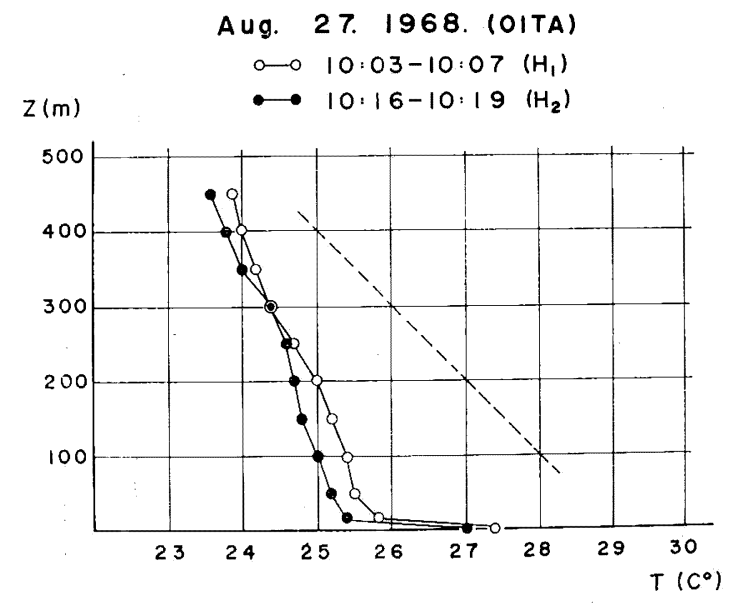

Fig. 29. Same as Fig. 22 but for 10:00 27th.

(a) $150 \mathrm{~m}$-source dispersion The concentration profile at $x=2.6 \mathrm{~km}$ is given in Fig. 30. $\bar{z}$ is $237 \mathrm{~m}$ and $\sigma_{z}$ is $31 \mathrm{~m}$, the Pasquill stability being E-F. The result of surface concentration analysis is shown in Fig. 31. $z$ varies as follows.

\begin{tabular}{c|cccl}
\hline$x$ & $(0)$ & $(2.6)$ & 5.0 & $7.0 \mathrm{~km}$ \\
\hline $\bar{z}$ & $(150)$ & $(240)$ & 125 & $125 \mathrm{~m}$ \\
\hline
\end{tabular}

The tracer cloud ascended near the source and then descended. The same result is obtained in the 12:00 experiment of the same day, as will be stated later. There exists another evidence showing that the ascending motion occurred near the source, which in turn serves to prove the reliability of the analysis. 


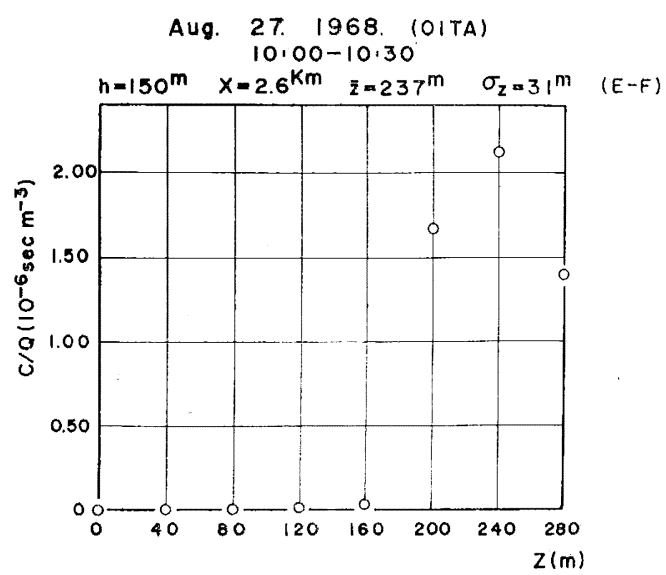

Fig. 30. Same as Fig. 23 but for 10:00 27th.

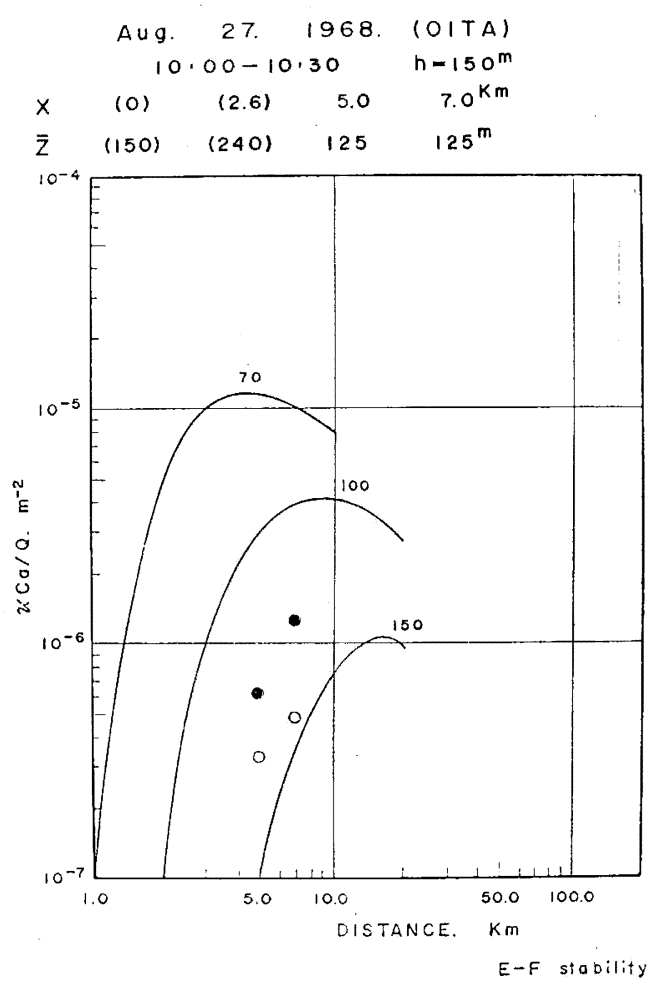

Fig. 31. Same as Fig. 24 but for Pasquill stability E-F and 10:00 27th.

Because of the marked rise of the tracer cloud near the source, the surface concentration is zero or very low down to $3.0 \mathrm{~km}$-arc, and the analysis of surface concentration is possible only at $5.0 \mathrm{~km}$-arc and $7.0 \mathrm{~km}$-arc. 
Aug. $27.1968 . \quad$ (OITA)
$10: 00-10: 30$
$h=0^{m} \quad x=2600^{m}$

- $\bar{z}=65^{\mathrm{m}} \quad \sigma_{\mathrm{z}}=65^{\mathrm{m}} \quad$ (D)

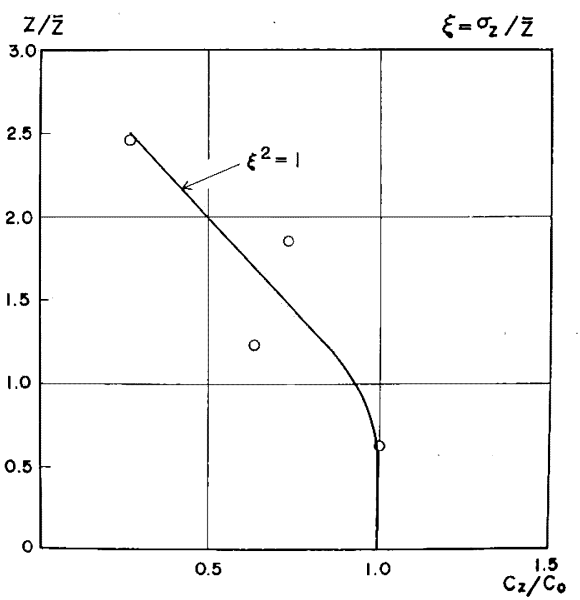

Fig. 32. Same as Fig. 25 but for 10:00 27th.

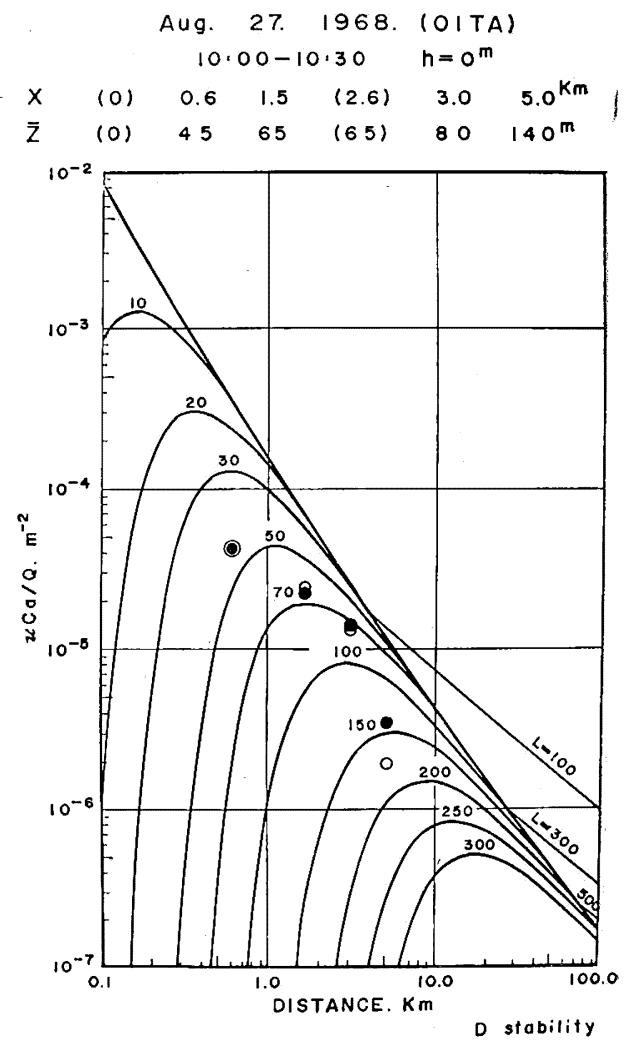

Fig. 33. Same as Fig. 26 but for 10:00 27th. 
(b) Surface-source dispersion The concentration profile at $x=2.6 \mathrm{~km}$ is shown in Fig. $32, \bar{z}$ is $65 \mathrm{~m}$ and $\sigma_{z}$ is $65 \mathrm{~m}$, the Pasquill stability being D. The stability of the surface source is distinctly higher than that of the $150 \mathrm{~m}$ source.

The result of surface concentration anysis is shown in Fig. 33, and $\bar{z}$ varies as follows.

\begin{tabular}{l|rrrrrl}
\hline \hline$x$ & $(0)$ & 0.6 & 1.5 & $(2.6)$ & 3.0 & $5.0 \mathrm{~km}$ \\
\hline $\bar{z}$ & $(0)$ & 45 & 65 & $(65)$ & 80 & $140 \mathrm{~m}$ \\
\hline
\end{tabular}

The rise of the tracer cloud is nearly the same as that of the corresponding one in the 25th August experiment.

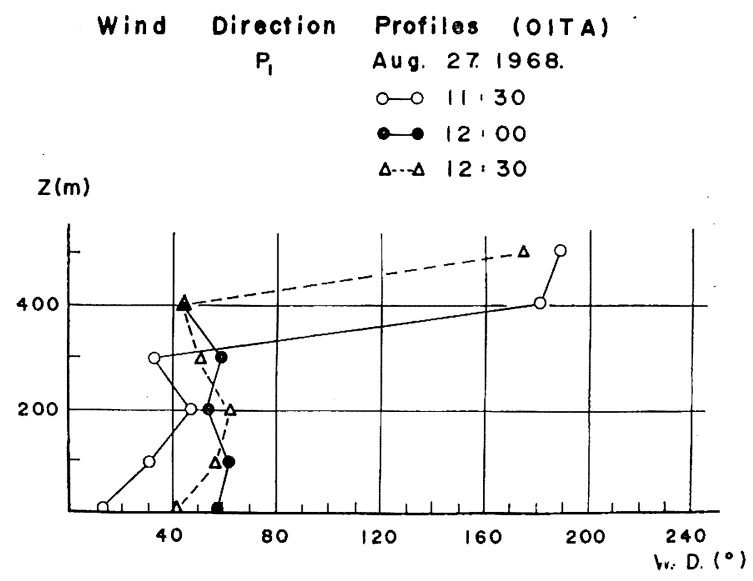

Fig. 34. Same as Fig. 19 but for 11:30-12:30 27th.
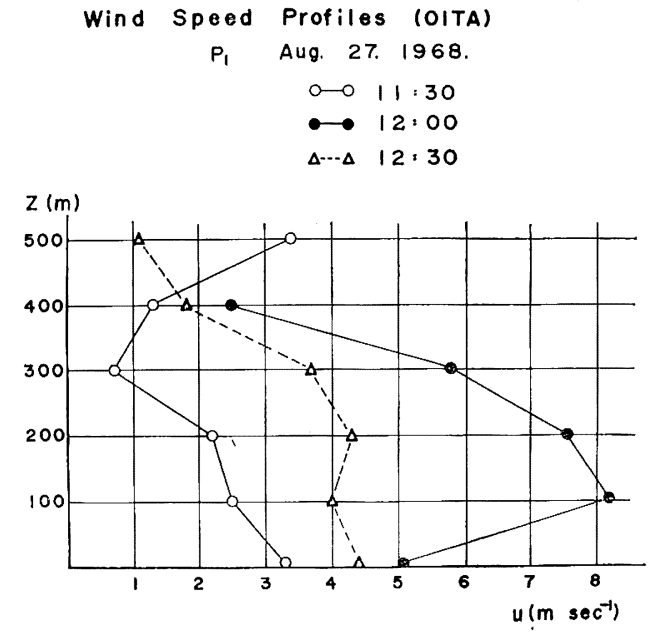

Fig. 35. Same as Fig. 20 but for 11:30-12:30 27th. 


\subsection{2:00 27th August 1968}

The wind profiles are shown in Figs. 34 and 35, and the temperature profile is shown in Fig. 36. The stratification is more stable than that of 10:00 and below the $300 \mathrm{~m}$ level the layer is isothermal.

(a) $150 \mathrm{~m}$-source dispersion The concentration profile was obtained at two points, $x=880 \mathrm{~m}$ and $x=2.6 \mathrm{~km}$ (Figs. 37 and 38 ). Fig. 37 shows that $\bar{z}$ is larger than $280 \mathrm{~m}$, and according to Fig. $38, \bar{z}$ is $175 \mathrm{~m}$ and $\sigma_{z}$ is $34 \mathrm{~m}$, the Pasquill stability being E-F.

The result of analysis is given in Fig. 39 , and $\bar{z}$ varies as follows.

\begin{tabular}{c|ccccc}
\hline$x$ & $(0)$ & $(0.88)$ & $(2.6)$ & 5.0 & $7.0 \mathrm{~km}$ \\
\hline $\bar{z}$ & $(150)$ & $>280$ & $(175)$ & 100 & $80 \mathrm{~m}$ \\
\hline
\end{tabular}

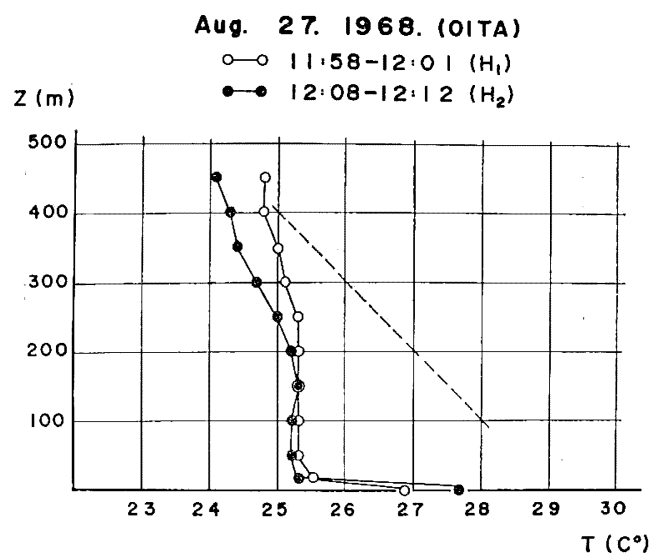

Fig. 36. Same as Fig. 22 but for 12:00 27th.

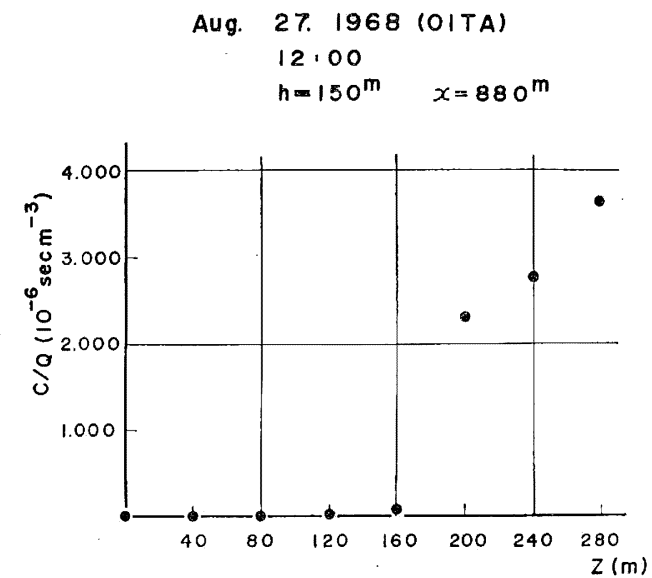

Fig. 37. Same as Fig. 23 but for $880 \mathrm{~m}$ downwind and 12:00 27th. 


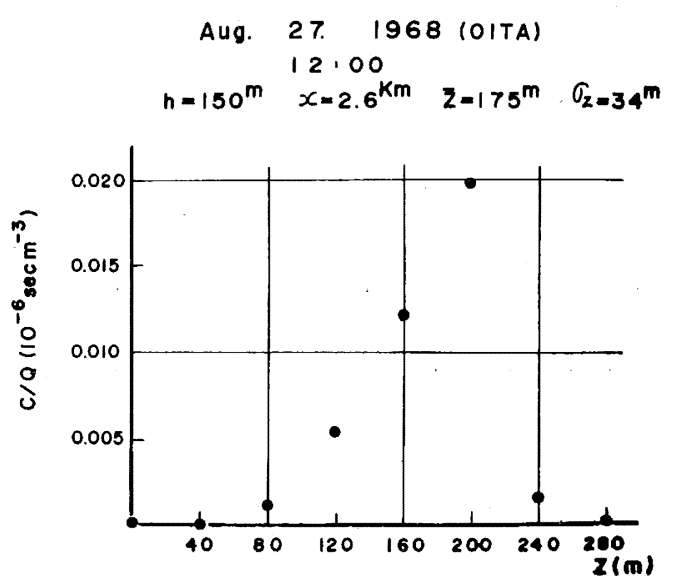

Fif. 38. Same as Fig. 23 but for 12:00 27th.

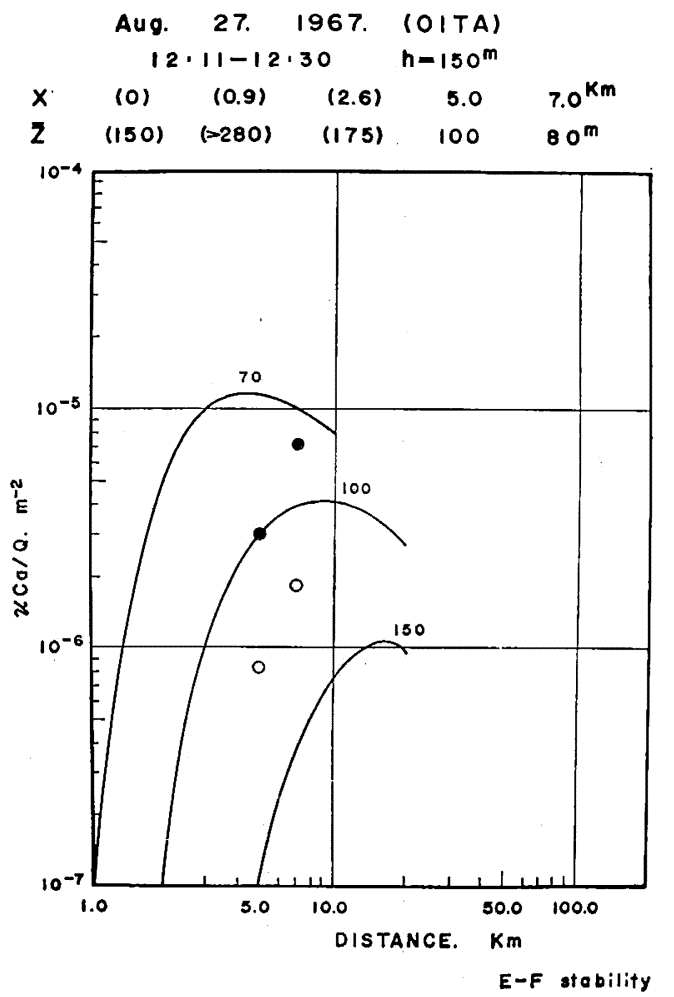

Fig. 39. Same as Fig. 31 but for 12:00 27th.

The rise of the tracer cloud is large near the source, while beyond $880 \mathrm{~m}$ it continues to descend. The surface concentration data are available only at $5.0 \mathrm{~km}$-arc and $7.0 \mathrm{~km}$-arc. The height of tracer could is shown in Fig. 40 rather schematically, together with the topography. It seems that the vertical current is more pronounced than that at 10:00. 
The variation of tracer cloud height with downwind distance

Aug. $27,12: 11-12: 30$ (O1TA)

$Z(m)$

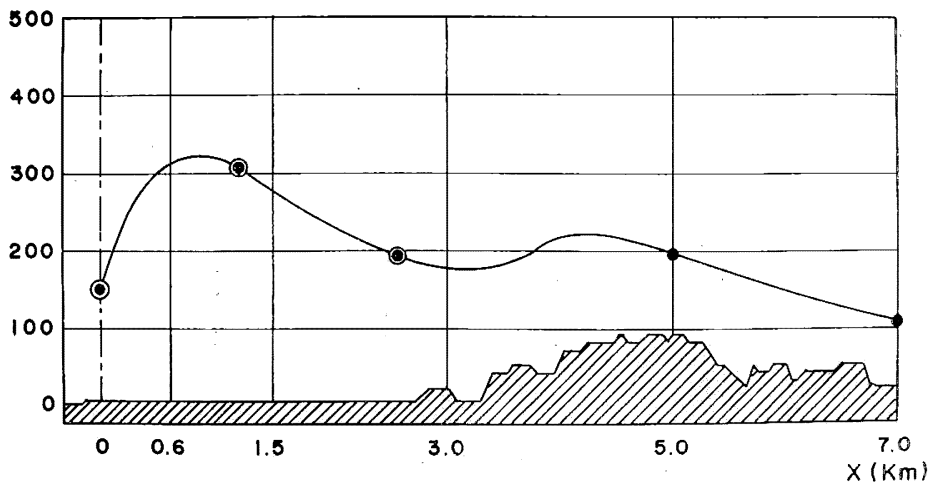

Fig. 40. Tracer cloud height and topography (12:00 27th Aug., Oita City)'.

Aug. 27. 1968. (OITA)

$12: 00-12: 30$

$h=0^{m} \quad x=2600^{m}$

- $\bar{z}=60^{m} \quad \sigma_{z}=60^{m} \quad(0)$

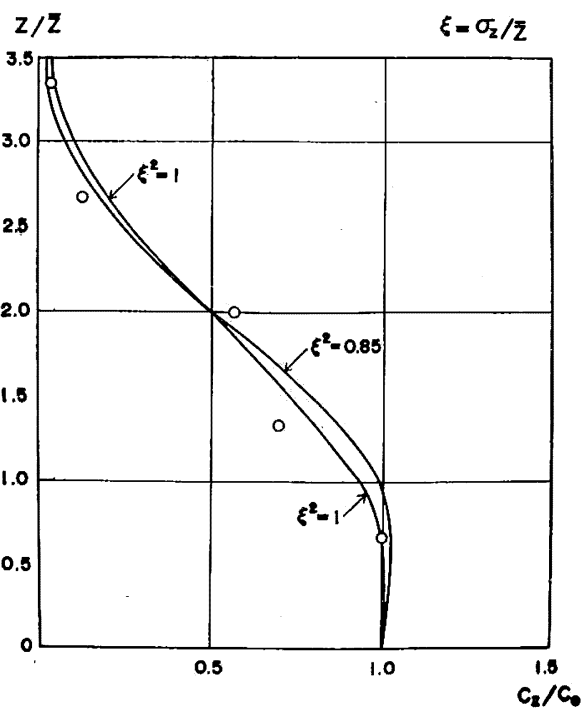

Fig. 41. Same as Fig. 32 but for 12:00 27th.

(b) Surface-source dispersion The concentration profile at $x=2.6 \mathrm{~km}$ is shown in Fig. $41 \cdot \bar{z}$ is $60 \mathrm{~m}$ and $\sigma_{z}$ is $60 \mathrm{~m}$, so the Pasquill stability is D. The result of surface concentration analysis is shown in Fig. 42. $\bar{z}$ varies with the downwind distance as follows. 


\begin{tabular}{r|rrrrrl}
\hline$x$ & $(0)$ & 0.6 & 1.5 & $(2.6)$ & 3.0 & $5.0 \mathrm{~km}$ \\
\hline $\bar{z}$ & $(0)$ & 0 & 35 & $(60)$ & 60 & $160 \mathrm{~m}$ \\
\hline
\end{tabular}

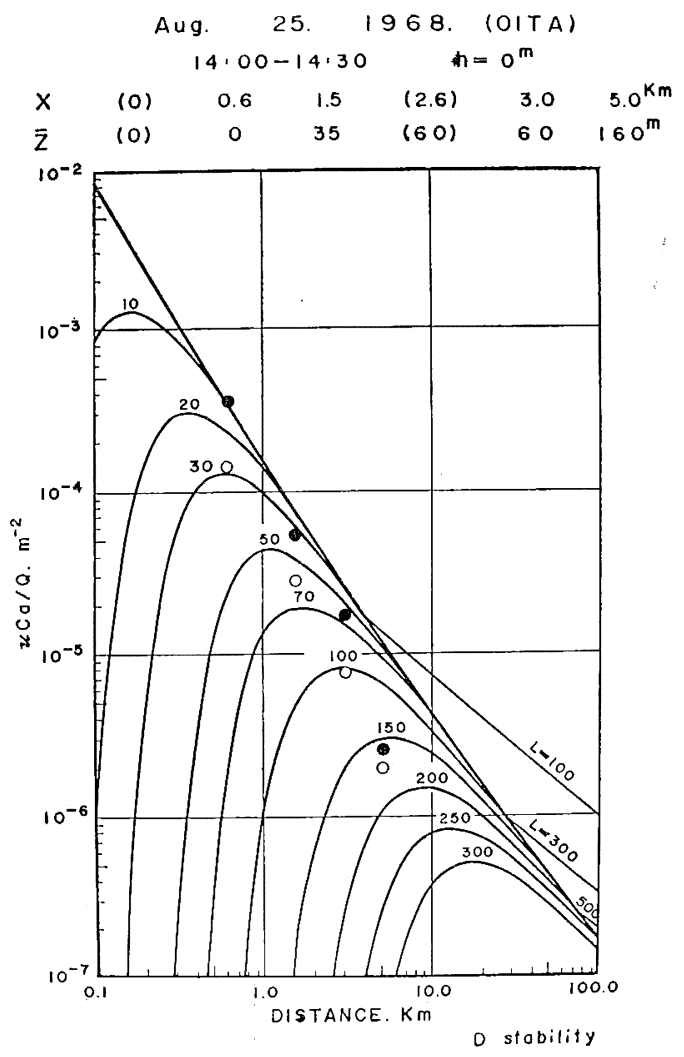

Fig. 42. Same as Fig. 33 but for 12:00 27th.

The rise of the tracer cloud with the downwind distance is gradual, and seems to have no direct relation to the vertical motion revealed from the analysis of $150 \mathrm{~m}$ source dispersion. It appears that the vertical current associated with $150 \mathrm{~m}$-source dispersion is of upper layer origin.

\subsection{Characteristics of dispersion over Oita City}

The most noteworthy result is that the Pasquill stability of surface-source dispersion is higher than that of elevated-source dispersion. This is naturally to be expected, since near the surface there are more factors likely to enhance the dispersion, such as roughness, thermal stability and so on. However, this is the case with a rather flat area like Oita City. Over a complicated terrain such as Kainan City the Pasquill stability of elevated-source dispersion is higher than that of surface-source dispersion.

It is also to be noticed that the Pasquill stability itself is higher over Kainan City than over Oita City. Certainly the stratification is somewhat more stable over Oita City. However, the large difference of Pasquill stability between the two cities is 
not to be attributed to the difference of thermal stratification alone.

The rise of the tracer cloud with the downwind distance is gradual over Oita City compared with that over Kainan City, whether the source is elevated or at the surface.

The abnormal rise of the tracer near the source on 27th may be attributed to the presence of a small vertical motion system.

\section{Conclusion}

The elevated-souruce dispersion was compared with the simultaneous surfacesource dispersion, by making use of the dispersion data over Kainan City and Oita City. Oita City has a relatively flat terrain, while Kainan City is situated in a valley surrounded by mountains 150 to $400 \mathrm{~m}$ high.

Over Kainan City the Pasquill stability of $200 \mathrm{~m}$-source dispersion is B or B$\mathrm{C}$, while that of the corresponding surface-source dispersion is B-C or C. Namely the Pasquill stability for the surface source is somewhat lower than that for the $200 \mathrm{~m}$ source. Over Oita City the Pasquill stability of $150 \mathrm{~m}$-source dispersion is D-E or E$\mathrm{F}$, while that of the correponding surface-source dispersion is all D. The Pasquill stability for the surface source is definitely higher than that for the $150 \mathrm{~m}$-source.

In general the height of the tracer cloud increases with the downwind distance. This seems reasonable, since the sea breeze carrying the tracer invades over a heated land. The rise of the tracer cloud is more remarkable over a complicated terrain than over a relatively flat terrain. The analysis of surface concentration hitherto made assuming no rise of the tracer with the downwind distance will more or less overestimate the vertical dispersion parameter $\sigma_{z}$.

The rise of the tracer from the surface source offers a special interest. The rise is 60 to $80 \mathrm{~m}$ at $3 \mathrm{~km}$ downwind over a flat terrain, while over a complicated terrain it is much larger. When the Pasquill stability is low, such rise will exert a marked effect upon the surface concentration.

\section{References}

SAKurabA, S., 1969: The elevation of tracer cloud over an urban area. Presented to the Symposium on "Multiple Source Urban Diffusion Models" held at Chapel Hill, N.C.

TURNer, D.B., 1967: Workbook of atmospheric dispersion estimates. Public Health Service, USA.

VAughan, L.M. and R.W. McMullen, 1968: Statistical analysis of particle size distributions from field samples obtained during St. Louis FP tracer trials. Technical Report, No. 145, Aerosol Lab., Metronics Associates, INC. 


\title{
地表煙源拡散と高煙源拡散の比較
}

\author{
桜庭信一, 森口 実, 山路 勲
}

和歌山県海南市では $200 \mathrm{~m}$ 煙源と地表煙源から，大分市では $150 \mathrm{~m}$ 煙源と地表煙源から，同時にトレー サーが散布され，高煙源拡散と地表煙源拡散の同時比較がなされた。高煙源と地表煙源では散布するトレー サー (FP) の色を変えている。

海南市は北と南を 150〜400 m の丘陵または山に囲まれた東西に延びる溪谷の町で, 西端が海に面してい る。大分市は北が海に面し，背後地が丘陵地であるが，トレーサーは比較的平坦地上を流れた。

解析は, 風下距離の少なくとも一点で, 濃度の鉛直分布とトレーサー到達時刻が得られたもののみについ てなされた。これからトレーサー雲の高さ, 濃度の鉛直幅 (Pasquill 安定度), 輸送速度が得られ, 地表濃 度の解析が正確になる。

地形の複雑な海南市では, 高煙源の方が地表煙源より Pasquill 安定度が若干高いが，大分市では逆であ る。また Pasquill 安定度そのものは海南市の方が，高・低煙源にかかわらず，気象条件はそれはど違わな いのに，圧倒的に大きい。これは拡散に及ぼす地形の影響が大きいことを示すものである。 